\title{
Rapid and transient expression of Ets2 in mature macrophages following stimulation with cMGF, LPS, and PKC activators
}

\author{
Kim E. Boulukos, ${ }^{1,3}$ Philippe Pognonec, ${ }^{1,4}$ Eric Sariban, ${ }^{2,5}$ Manuella Bailly, ${ }^{1}$ Christian Lagrou, ${ }^{1}$ and \\ Jacques Ghysdael ${ }^{1,6}$ \\ ${ }^{1}$ Institut de la Santé et de la Recherche Médicale U 186/Centre National de la Recherche Scientifique (CNRS) UA 041160, \\ Institut Pasteur, 59019, Lille, France; ${ }^{2}$ Laboratory of Clinical Pharmacology, Dana Farber Cancer Institute, Harvard Medical \\ School, Boston, Massachusetts 02115 USA
}

\begin{abstract}
We reported previously that Ets2 is expressed in normal and transformed macrophages. We show here that the expression of both c-ets-2 mRNA and proteins is induced rapidly and transiently in chicken nondividing bone marrow-derived macrophages but not in E26-transformed myeloblasts in response to chicken myelomonocytic growth factor (cMGF), an avian hematopoietic growth factor required for survival, proliferation, and colony formation of avian myeloid cells. c-ets-2 expression is also rapidly induced in chicken bone marrow-derived macrophages, human monocytes, and mouse peritoneal macrophages in response to LPS and/or PKC activators. The rapid induction of Ets2 after treatment of chicken bone marrow-derived macrophages by cMGF is blunted after down-regulation or inactivation of PKC, suggesting a role of PKC in the cMGF-induced signal transduction pathway. Because Ets2 is localized in the nucleus of macrophages and binds to DNA in vitro, the kinetics of its expression suggest a role for Ets2 in the transduction within the nucleus of specific signals received at the cell membrane and involved in securing the survival and/or the development of functional competence of these cells.
\end{abstract}

[Key Words: c-ets-2; proto-oncogene; PKC; cMGF; macrophages; early response genes]

Received July 18, 1989; revised version accepted December 11, 1989.

E26 is a replication-defective retrovirus that causes erythroblastosis and myeloblastosis in chickens and transforms erythroblasts and myeloblasts in culture (Graf et al. 1979; Moscovici et al. 1981, 1983; Radke et al. 1982). Together with a partial gag gene, the genome of E26 contains the oncogenes $\mathrm{v}-m y b^{\mathrm{E}}$ (Roussel et al. 1979) and v-ets (Leprince et al. 1983; Nunn et al. 1983), which are both implicated in the oncogenic potential of E26 (Beug et al. 1984; Golay et al. 1988; Nunn and Hunter 1989). The c-ets gene family includes genes with sequence identity to the v-ets oncogene and consists of c-ets-1 (Chen 1985; Watson et al. 1985; Ghysdael et al. 1986a), the progenitor to v-ets (Gegonne et al. 1987; Chen 1988; Duterque-Coquillaud et al. 1988; Leprince et al. 1988), c-ets-2 (Watson et al. 1985; Ghysdael et al. 1986b; Boulukos et al. 1988), erg (Rao et al. 1987; Reddy et al. 1987), and elk (Rao et al. 1989). The chicken 54-kD c-ets-1 (Ets1) and 58- to 64-kD c-ets-2 (Ets2) gene

Present addresses: ${ }^{3}$ Department of Biochemistry, New York University Medical Center, New York, New York 10016 USA; ${ }^{4}$ Department of Biochemistry and Molecular Biology, The Rockefeller University, New York, New York 10021 USA; ${ }^{5}$ Hopital Universitaire des Enfants Reine Fabiola, Université Libre de Bruxelles, Brussels, Belgium.

'Corresponding author. products are nuclear phosphoproteins (Boulukos et al. 1988; Pognonec et al. 1988, 1989/ that share two domains of identity of 96 and 175 amino acids in their amino- and carboxy-terminal domains, respectively (Boulukos et al. 1988).

Etsl is a nuclear chromatin-associated protein (Pognonec et al. 1989) highly expressed in lymphoid cells and tissues (Chen 1985; Ghysdael et al. 1986a), which displays DNA-binding capacity in vitro (Pognonec et al. 1989|. Stimulation of thymocytes with mitogenic doses of concanavalin $\mathrm{A}$ results in the rapid $\mathrm{Ca}^{2+}$-dependent phosphorylation of Ets1 (Pognonec et al. 1988). These $\mathrm{Ca}^{2+}$-dependent phosphorylation events result in both a loss of affinity of Etsl for chromatin and its ability to bind to DNA in vitro (Pognonec et al. 1989), suggesting a role for Etsl as a nuclear mediator of the $\mathrm{Ca}^{2+}$ signal transduction pathway in lymphoid cells.

The c-ets- 2 gene is expressed in a wide variety of tissues (Bhat et al. 1987), and its expression has been proposed to be intrinsically linked to cell proliferation in mouse regenerating liver and fibroblasts (Bhat et al. 1987). We reported previously that Ets2 expression is prominent in avian macrophages and that synthesis of these proteins is induced upon 12-O-tetradecanoyl- 
phorbol 13-acetate (TPA)-induced differentiation of AMV-transformed monoblasts into macrophage-like cells (Ghysdael et al. 1986b). Here we show that c-ets-2 is rapidly and transiently induced in chicken nondividing bone marrow-derived macrophages (BMM) in response to an avian hematopoietic growth factor, chicken myelomonocytic growth factor (cMGF), required for survival, proliferation, and colony formation of avian myeloid cells, as well as to bacterial lipopolysaccharide (LPS) and protein kinase $\mathrm{C}(\mathrm{PKC})$ activators. Ets2 is localized in the nucleus of macrophages and, like Etsl, displays DNA binding activity in vitro. These properties show that in macrophages, transient c-ets-2 expression is not necessarily linked to cellular proliferation but could be involved in cellular survival and/or the development of functional competence.

\section{Results}

Induction of c-ets-2 gene expression in chicken macrophages

We reported previously that Ets 2 is expressed in chicken BMM and that its synthesis is specifically induced upon treatment of AMV-transformed monoblasts with the phorbol ester TPA (Ghysdael et al. 1986b). Because signal transduction by TPA involves direct activation of PKC in cells, we hypothesized that the induction of Ets2 by TPA in mature cells of the myelomonocytic lineage could reflect an event bypassing a ligand-receptor interaction occurring at the cell surface. The only well-characterized avian hematopoietic stimulating factor in myeloid cells is cMGF, a 201-amino-acid glycoprotein required for growth and survival of these cells and for colony formation of myeloid precursor cells (Leutz et al. 1984, 1989). cMGF is distinct from known mammalian colony-stimulating factors (CSFs), although a mammalian homolog of cMGF probably exists (Leutz et al. 1989). Therefore, we decided to investigate whether cMGF was able to induce c-ets-2 gene expression in cells of the myeloid lineage. Growth in tissue culture of chicken bone marrow cells in the continuous presence of cMGF results in the proliferation of nonadherent myeloid progenitor cells and in their terminal differentiation into adherent macrophage-like cells (BMM). These adherent BMM form a nongrowing cell population as evidenced by $\left[{ }^{3} \mathrm{H}\right.$ thymidine incorporation (data not shown), which requires the continuous presence of cMGF for survival. To analyze whether $\mathrm{CMGF}$ is a signal sufficient to induce c-ets-2 gene expression in BMM, cultures were deprived of cMGF for $48 \mathrm{hr}$ and then either left untreated or restimulated with cMGF. After $1 \mathrm{hr}$, cultures were pulse-labeled with $\mathrm{L}-\left[{ }^{35} \mathrm{~S}\right]$ methionine for $20 \mathrm{~min}$ and analyzed for Ets 2 protein content by immunoprecipitation analysis using an Ets2-specific peptide antiserum (Boulukos et al. 1988) and SDS-PAGE. Whereas stimulation of CMGF-deprived BMM cells with cMGF did not affect total protein synthesis /data not shown), it increased $\sim 10$ times the synthesis of Ets2 (Fig. 1A). The four protein species of 58, 60, 62, and 64 $\mathrm{kD}$ are no longer detected using the Ets2-specific anti-

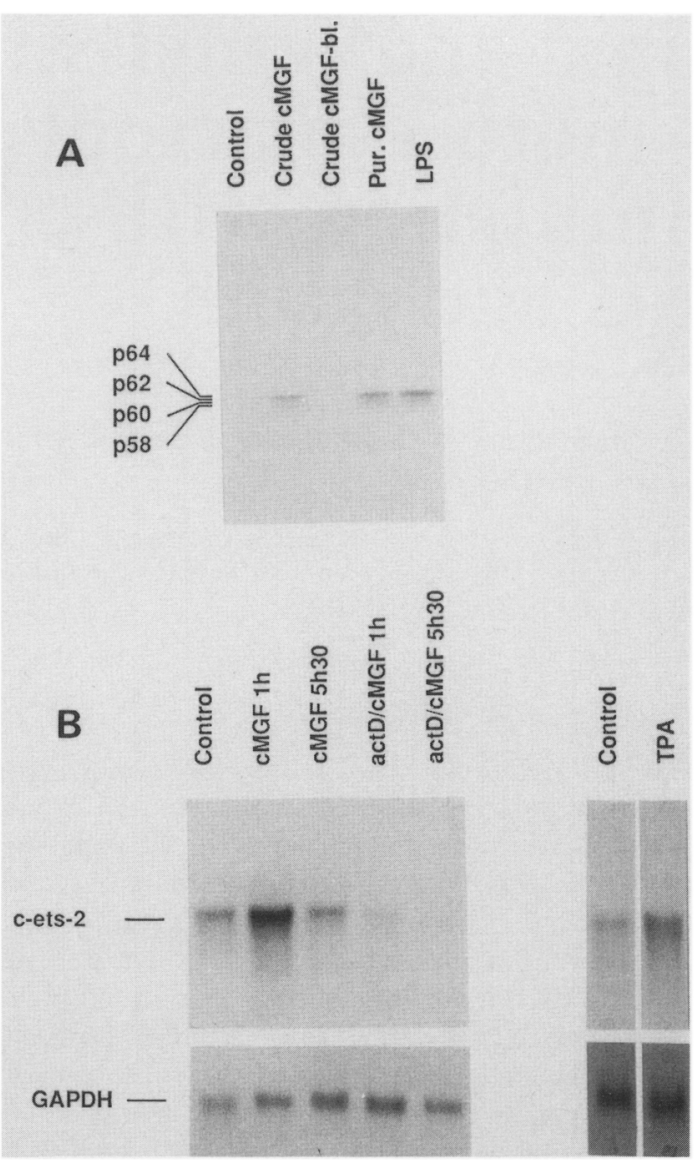

Figure 1. (A) Expression of Ets2 in chicken BMM. Adherent, nondividing chicken BMM were deprived of cMGF for $48 \mathrm{hr}$ and cells either were left untreated or were incubated in the presence of nonpurified cMGF (crude cMGF) or a highly purified preparation of cMGF (pur. cMGF; Leutz et al. 1984) or LPS for 1 hr. Cells were pulse-labeled with $500 \mu \mathrm{Ci} / \mathrm{ml}$ of L-[ $\left.{ }^{35} S\right]$ methionine for $20 \mathrm{~min}$ and lysed, and immunoprecipitations were carried out with $10^{7}$ radioactive counts of each lysate with an Ets2-specific peptide antiserum or with the Ets2-specific peptide antiserum blocked with an excess of the immunogenic peptide (crude cMGF-bl.) and analyzed by SDS-PAGE. (B) RNA blot hybridization. Total RNA $(10 \mu \mathrm{g})$ was isolated from untreated chicken BMM deprived of cMGF for $48 \mathrm{hr}$ or chicken BMM deprived of cMGF for $48 \mathrm{hr}$ and restimulated with either cMGF for 1 or $5.5 \mathrm{hr}$ in the absence or presence of actinomycin $\mathrm{D}$ or TPA for $1 \mathrm{hr}$. The RNAs were resolved by formaldehydeagarose gel electrophoresis, transferred to nylon membranes, and hybridized to ${ }^{32} \mathrm{P}$-labeled c-ets-2 probe or, after stripping, rehybridized to GAPDH as a control.

serum blocked with an excess of the purified peptide immunogen (Fig. 1A) and therefore correspond to the c-ets2 gene products identified previously in chicken cells (Ghysdael et al. 1986b; Boulukos et al. 1988). As described previously, the $60-$ and $64-\mathrm{kD}$ species represent phosphorylated versions of the $58-\mathrm{kD}$ and $62-\mathrm{kD}$ species, which probably result from initiation of translation at two distinct ATGs (initiation codons) (Boulukos et al. 1988). The source of cMGF used in this experiment is a conditioned medium obtained after LPS-stimulation of 
the MC29-transformed macrophage cell line HBC-1 (Leutz et al. 1984). LPS, an agent known to stimulate many facets of macrophage functional activation (for review, see Hamilton and Adams 1987), also induces Ets2 expression in BMM (Fig. 1A). To analyze whether the induction of Ets2 in BMM after treatment with the HBC-1-conditioned medium resulted from a true response to CMGF or a response to LPS, we analyzed the effect of a highly purified preparation of cMGF (Leutz et al. 1984). As shown in Figure 1A, treatment of cMGFdepleted BMM with purified CMGF also results in an induction of Ets2 at levels similar to those observed after treatment with either the HD11-conditioned medium or with LPS.

To test whether the purified preparation of $\mathrm{cMGF}$ is indeed free of LPS, mouse peritoneal macrophages were selected, as the effects of LPS and CMGF can be separated in this system. Bacterial cell wall products, including LPS, are known to fully activate the functional response of mouse peritoneal macrophages (Adams and Hamilton 1984; Bonvini et al. 1986). In contrast, cMGF does not have a biological activity in murine cells (Leutz et al. 1989). Among the early changes induced by LPS in mouse peritoneal macrophages is the alteration of several competence genes first described in growth factorstimulated fibroblasts such as c-fos, c-myc, JE, and KC (Introna et al. 1986, 1987). Thus, we examined c-fos protein expression following a 1-hr treatment of mouse peritoneal macrophages with either LPS or purified cMGF. As expected, a 1-hr treatment of mouse peritoneal macrophages with LPS results in the activation of c-fos expression, whereas no activation of c-fos is observed after a 1 -hr treatment with purified $\mathrm{cMGF}$; this demonstrates that the purified $\mathrm{CMGF}$ is indeed devoid of LPS (data not shown). In line with the observation in chicken BMM, Ets2 expression is induced by LPS in mouse peritoneal macrophages (Fig. 2). As early as 30 min after LPS treatment of these cells, the level of the 55-kD mouse Ets2 (mo-p55-ets-2; Pognonec et al. 1989) is increased as detected with an Ets2-specific peptide serum. Two additional Ets2 products (indicated by arrows in Fig. 2) are detected that represent phosphorylated forms of mo-p55 $5^{\text {cets-2 }}$, because these forms are converted into the $55-\mathrm{kD}$ species upon alkaline phosphatase treatment (data not shown).

\section{Kinetics of $c$-ets-2 induction in $c M G F$-treated avian macrophages}

We next determined the kinetics of chicken c-ets-2 protein and RNA expression in BMM in response to cMGF. As seen in Figure 3A, cMGF treatment of BMM leads to a rapid increase in Ets2 synthesis, peaking between 1 and $2 \mathrm{hr}$ after cMGF treatment. Furthermore, this increased expression is transient, because the level of Ets 2 returns to levels similar to those observed in untreated cells $4.5 \mathrm{hr}$ after cMGF treatment. In contrast to the induction of Ets2, the low level of the 54-kD Ets1 observed in BMM was not found to be affected by treatment with either CMGF or LPS (Fig. 3B).

Consistent with the results presented at the protein

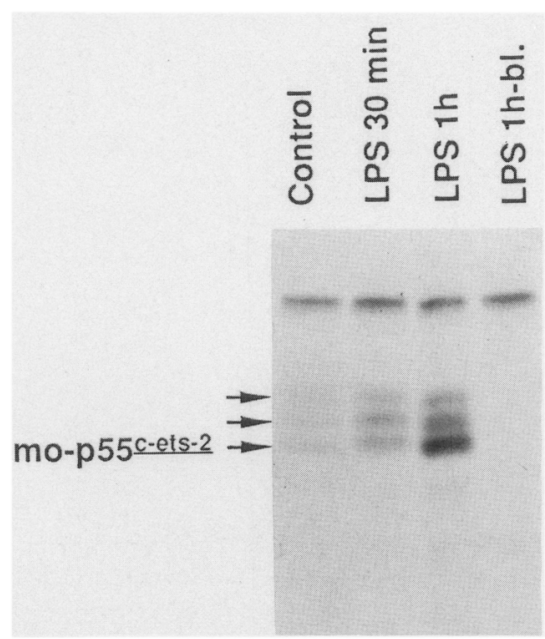

Figure 2. LPS induction of Ets2 in mouse peritoneal macrophages. Twenty-four hours after isolating mouse peritoneal macrophages, cells either were left untreated (control) or were treated with LPS for $30 \mathrm{~min}$ (LPS $30 \mathrm{~min}$ ) or $1 \mathrm{hr}$ (LPS $1 \mathrm{hr}$ ). Cells were then pulse-labeled with $\mathrm{L}-{ }^{35} \mathrm{~S} \mid$ methionine for $20 \mathrm{~min}$ and lysed, and immunoprecipitations were carried out with $10^{7}$ radioactive counts of each lysate with an Ets2-specific peptide antiserum or with the Ets2-specific peptide antiserum blocked with an excess of the immunogenic peptide (LPS lh-bl.). Immunoprecipitates were analyzed by SDS-PAGE. The major mouse Ets2 (mo-p55 c-ets-2), as well as the slower migrating phosphorylated forms of Ets2, are indicated by arrows.

level, Northern blot analysis showed that treatment of cMGF-starved BMM with cMGF leads to a rapid increase in the level of the $4.0-\mathrm{kb}$ c-ets-2 RNA species (Fig. 1B). Most of this increase is probably transcriptional, as c-ets-2 RNA levels are not affected by cMGF treatment in the presence of actinomycin D. In fact, the level of c-ets-2 RNA appears even lower than that observed in untreated cells, a result reflecting the short half-life $K<1$ $\mathrm{hr}$ ) of c-ets-2 mRNA in macrophages (Fig. 1B; cf. lanes cMGF $1 \mathrm{hr}$, actD/cMGF $1 \mathrm{hr}$, and controls; see below).

The level of c-ets-2 mRNA is also rapidly increased by $1 \mathrm{hr}$ TPA treatment of cMGF-starved BMM (Fig. 1B). Because TPA is a direct activator of PKC and signal transduction by LPS also appears to involve PKC activation (Hamilton and Adams 1987), we investigated whether the induction of the c-ets-2 gene expression by cMGF in $B M M$ is dependent on the presence of functional PKC. Sustained TPA treatment of cells is known to lead to a down-regulation of PKC (Berridge and Irvine 1984). Therefore, BMM were pretreated with $50 \mathrm{ng} / \mathrm{ml}$ of TPA for $54 \mathrm{hr}$ or left untreated as a control, before restimulation of these cells for $1 \mathrm{hr}$ with either a purified preparation of cMGF or $100 \mathrm{ng} / \mathrm{ml}$ of TPA, followed by a 30min pulse-labeling with $\mathrm{L}-\left[{ }^{35} \mathrm{~S}\right]$ methionine. In the control samples, an increase in Ets2 synthesis is observed as the result of cMGF or TPA treatment, as expected (Fig. $3 \mathrm{C}$. In contrast, sustained treatment with TPA drastically reduces the ability of CMGF or TPA to induce Ets2 synthesis. In addition, we performed experiments using a potent $\mathrm{PKC}$ inhibitor, 1/5-isoquinolinyl-sulfonyl)-2- 
A

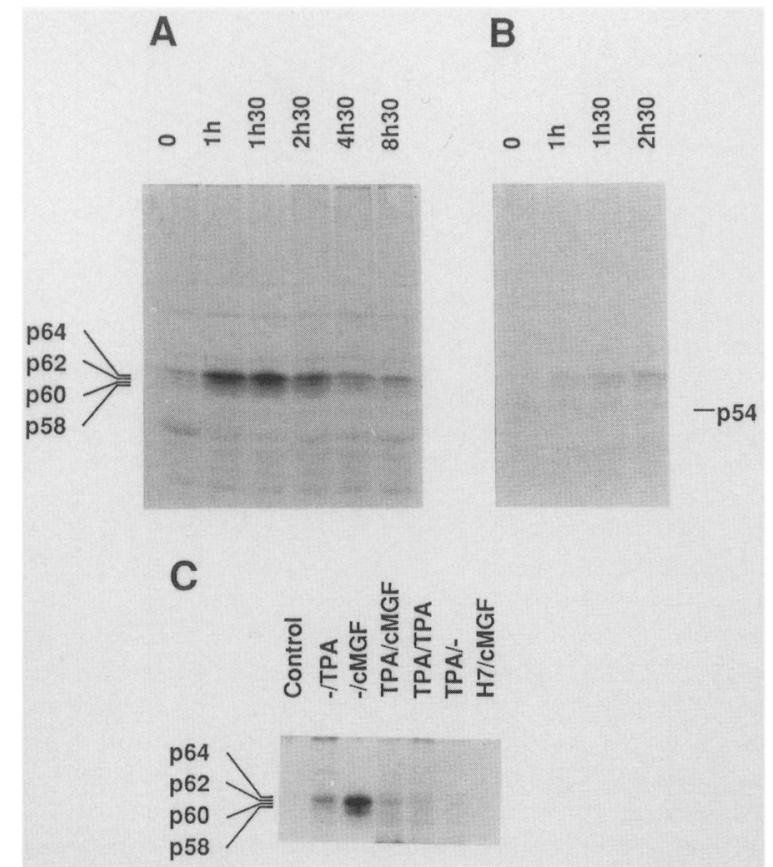

Figure 3. Kinetics of Ets2 induction in chicken BMM and dependence on the presence of a functional PKC. $(A$ and $B)$ BMM were starved of cMGF for $48 \mathrm{hr}$ and restimulated with cMGF for $1,1.5,2.5,4.5$, or $8.5 \mathrm{hr}$. Cells were then pulse-labeled with $500 \mu \mathrm{Ci} / \mathrm{ml}$ of $\mathrm{L}-{ }^{35} \mathrm{~S} \mid \mathrm{methionine}$ for $20 \mathrm{~min}$ and lysed, and immunoprecipitations were carried out with $10^{7}$ radioactive counts of each lysate. $(A)$ Lysates were immunoprecipitated with an Ets2-specific peptide antiserum; $(B)$ supernatants from the immunoprecipitation in $A$ were recovered and reimmunoprecipitated with a standard Ets antiserum immunoreactive with both Etsl and Ets2; $(C)$ after various pretreatments, as indicated, chicken BMM were pulse-labeled and lysed, and immunoprecipitations were carried out with an Ets2-specific peptide antiserum. (Control) Untreated BMM; (-/TPA and -/ cMGF) nonpretreated BMM treated with $100 \mathrm{ng} / \mathrm{ml}$ TPA or 10 $\mathrm{U} / \mathrm{ml}$ cMGF, respectively, for $1 \mathrm{hr}$; (TPA/cMGF and TPA/TPA), BMM pretreated with $50 \mathrm{ng} / \mathrm{ml}$ TPA for $54 \mathrm{hr}$ and treated with $10 \mathrm{U} / \mathrm{ml}$ cMGF or $100 \mathrm{ng} / \mathrm{ml} \mathrm{TPA}$, respectively, for $1 \mathrm{hr}$; (TPA/-) BMM treated with $50 \mathrm{ng} / \mathrm{ml}$ TPA for $54 \mathrm{hr} ;(\mathrm{H} 7)$ cMGF) BMM pretreated with $20 \mu \mathrm{M} \mathrm{H} 7$ overnight and treated with $10 \mathrm{U} / \mathrm{ml}$ cMGF for $1 \mathrm{hr}$. Unit definition of cMGF is as described by Leutz et al. (1984).

methylpiperazine (H7) (Kawamoto and Hidaka 1984). As shown in Figure 3C, overnight treatment of BMM with $20 \mu \mathrm{M} \mathrm{H} 7$ before 1-hr stimulation with cMGF leads to a complete block of Ets2 expression. Similar results were obtained when parallel cultures were pretreated with $100 \mu \mathrm{M} \mathrm{H} 7$ for $2 \mathrm{hr}$ and treated for $1 \mathrm{hr}$ with cMGF (data not shown). Taken together, these results indicate that cMGF activation of c-ets-2 gene products in BMM can occur via a PKC-dependent pathway.

\section{Treatment of human monocytes by PKC activators} results in the rapid expression of $c$-ets- 2

TPA treatment of normal human blood-derived monocytes induces these cells to acquire antigenic and biolog- ical characteristics of macrophages (Kiyotaki and Bloom 1984; Vassali et al. 1984; Todd et al. 1985; Radzioch et al. 1987; Sariban et al. 1987). As shown in Figure 4A, treatment of human peripheral blood monocytes with 33 mM TPA also results in a rapid increase in the 4.7- and 3.2-kb c-ets-2 RNA transcripts. c-ets-2 RNA levels are increased as early as $30 \mathrm{~min}$ following TPA treatment; however, this induction is not transient as compared with that observed in chicken BMM because it remains high until $12 \mathrm{hr}$ post-treatment (Fig. 4A). Similar results are observed in CMGF or TPA-treated chicken AMV-

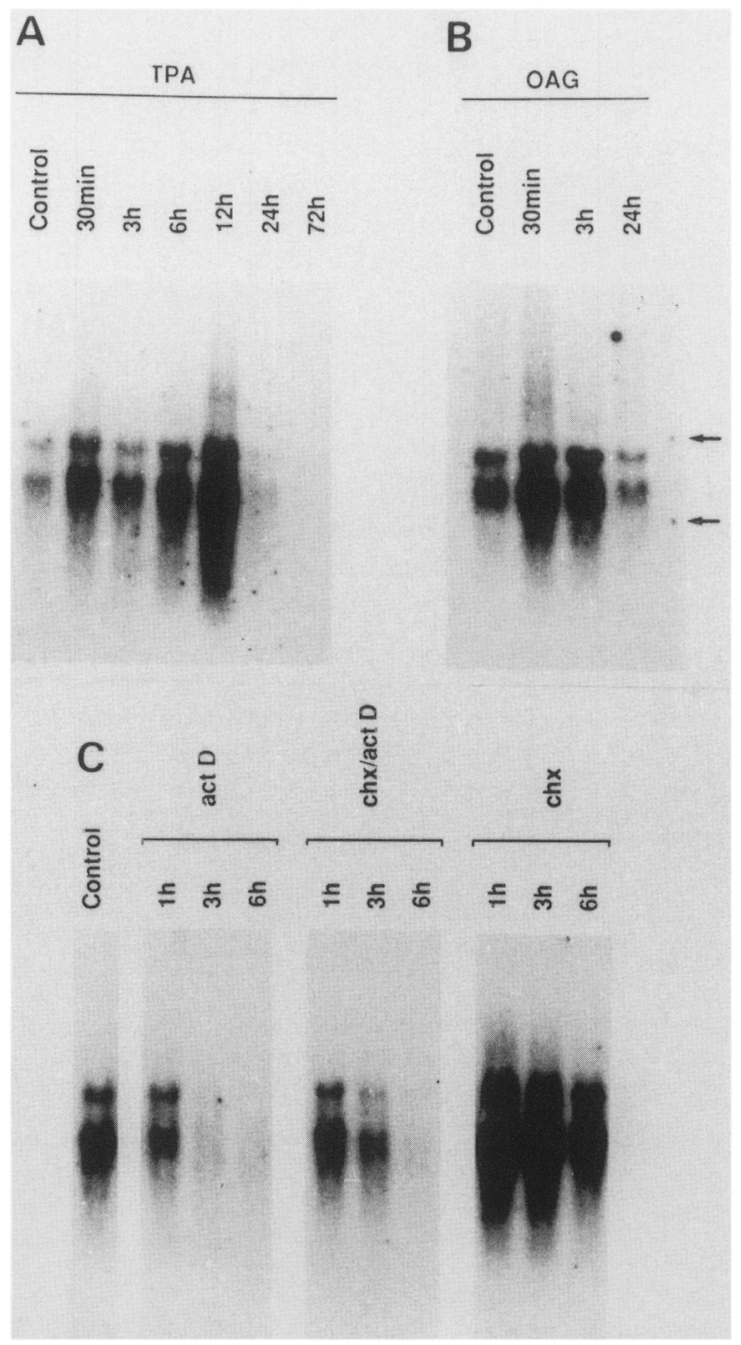

Figure 4. Kinetics of c-ets-2 RNA induction in human monocytes by PKC activators. $(A)$ RNA was isolated from either untreated normal human blood-derived monocytes or normal blood-derived monocytes treated with $33 \mathrm{nM}$ TPA for $30 \mathrm{~min}$ or $3,6,12,24$, or $72 \mathrm{hr} .(B)$ Normal human blood-derived monocytes were left untreated or treated with $500 \mathrm{nM}$ OAG for 30 min or 3 or $24 \mathrm{hr}$, before RNA extraction. (C) RNA was isolated from human monocytes treated with either $5 \mathrm{ng} / \mathrm{ml}$ actinomycin D alone, $10 \mu \mathrm{g} / \mathrm{ml}$ cycloheximide alone, or actinomycin $\mathrm{D}$ and cycloheximide together for 1, 3, or $6 \mathrm{hr}$ and analyzed as described previously (Sariban et al. 1987), using the 2.3-kb EcoRI human c-ets-2 probe (a generous gift of A. Gegonne). Ribosomal markers are indicated by arrows. 
transformed monoblasts (data not shown). Treatment of human monocytes with another PKC activator, the membrane-permeable diacylglycerol, 1-oleoyl-2-acetyl glycerol (OAG), also results in a rapid induction of c-ets2 (Fig. 4B). These results demonstrate that activation of the PKC pathway results in activation of the expression of c-ets-2 in both human monocytes and chicken macrophages.

The half-life of c-ets-2 RNA in human monocytes is $\sim 1 \mathrm{hr}$, as determined by chase treatment in the presence of actinomycin D (Fig. 4C). When performed in the presence of cycloheximide, actinomycin D chase experiments show that the c-ets-2 RNA half-life is increased (Fig. 4C), suggesting a requirement for continuous protein synthesis in the regulation of the short half-life of c-ets-2 RNA.

\section{c-ets-2 expression is not induced in E26-transformed myeloblasts}

Myeloid cells transformed by E26 represent a homogeneous population of immature myeloblasts that absolutely require cMGF for growth (Radke et al. 1982; Leutz et al. 1984). We investigated whether treatment of E26transformed myeloblasts with cMGF also results in c-ets-2 gene expression. E26-transformed myeloblasts were deprived of cMGF by incubation for $24 \mathrm{hr}$ in cMGF-depleted growth medium and then restimulated with either CMGF or TPA for various periods of time; c-ets-2 expression was analyzed by Northern blot hybridization. In contrast to observations in BMM, the expression of c-ets-2 is barely detectable in either exponentially growing E26-transformed myeloblasts (data not shown) or in E26-transformed myeloblasts deprived of cMGF for $24 \mathrm{hr}$ (Fig. 5). Furthermore, c-ets-2 expression is not induced by either CMGF or TPA treatment of

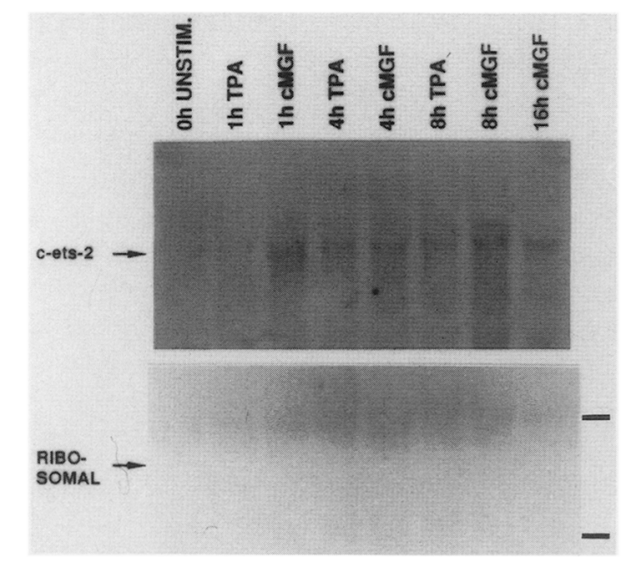

Figure 5. Expression of c-ets-2 in E26-transformed myeloblasts. RNA was extracted in guanidium isothiocyanate from a clone of E26-transformed myeloblasts either left untreated as a control or treated with either TPA or CMGF for $1,4,8$, or $16 \mathrm{hr}$. After centrifugation, RNA was electrophoresed in agarose gels and analyzed by ethidium bromide staining (bottom; positions of the $28 \mathrm{~S}$ and $18 \mathrm{~S}$ rRNAs are marked at right) or, after transfer to nylon blot, by hybridization with c-ets-2 cDNA probe (top).

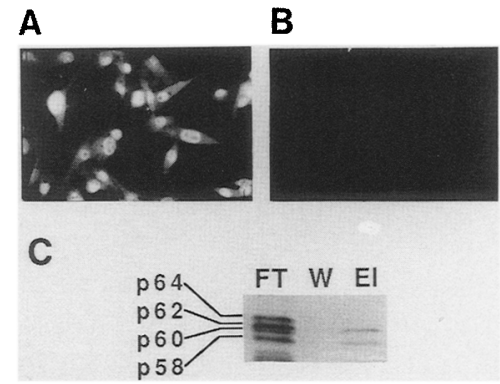

Figure 6. $(A$ and $B)$ Subcellular localization of Ets2 in macrophages. Cells of the HDll line were transferred to collagentreated coverslips, fixed in $3.5 \%$ paraformaldehyde, treated with $0.15 \mathrm{M}$ ethanolamine and permeabilized in $0.2 \% \mathrm{NP}-40$, and subcellular Ets2 localization was analyzed by immunofluorescence using an Ets2-specific peptide antiserum $(A)$ or the Ets2-specific peptide antiserum blocked with an excess of its peptide immunogen $(B) .(C)$ DNA binding of Ets2 in vitro. Monkey COS-1 cells transfected with $10 \mu \mathrm{g}$ of PKCR3-Ck-3.1 were labeled with $250 \mu \mathrm{Ci} / \mathrm{ml} \mathrm{L}$-[ $\left.{ }^{35} \mathrm{~S}\right]$ methionine, lysed, and incubated with native calf thymus DNA cellulose. Equivalent amounts of flowthrough (FT), wash (W), and elution (El) fractions were immunoprecipitated with an Ets2-specific peptide antiserum and analyzed by SDS-polyacrylamide gel electrophoresis.

these cells over a 16 -hr period. Similar results were obtained at the protein level (data not shown). These results suggest that the activation of c-ets-2 in response to cMGF or PKC activators depends on the maturation state of the myelomonocytic cells where c-ets-2 expression is rapidly and transiently activated in fully differentiated macrophages but not in immature cells of the myelomonocytic lineage.

\section{Subcellular localization and DNA-binding activity of Ets2 products}

We showed previously that Ets2 transiently expressed from the c-ets-2 expression vector construct PKCR3-Ck3.1 in monkey COS-1 cells is localized in the nucleus of these cells (Boulukos et al. 1988). In light of these results, we analyzed the subcellular localization of endogenous Ets2 in avian macrophages. Cells of the HD11 macrophage cell line were transferred to collagen-treated coverslips, and subcellular localization of Ets2 was analyzed by indirect immunofluorescence using the Ets2specific peptide antiserum. As shown in Figure 6A, a high level of immunofluorescence is observed exclusively in the nuclei of HDll cells when analyzed with the Ets2-specific peptide antiserum (Fig. 6A). This nuclear immunofluorescence signal is specific to Ets2 because it is not detected using either a nonimmune control serum (data not shown) or the Ets2 peptide antiserum blocked with an excess of the purified peptide immunogen (Fig. 6B).

We demonstrated recently that Etsl displays DNA binding activity in vitro and that the $\mathrm{Ca}^{2+}$-mediated phosphorylation of Ets1 results in a loss of this DNA binding capacity (Pognonec et al. 1989). Therefore, we 
investigated whether Ets 2 is also capable of binding to DNA in vitro. Monkey COS-1 cells transfected with PKCR3-Ck-3.1 were labeled with $\mathrm{L}-\left[{ }^{35} \mathrm{~S} \mid\right.$ methionine and lysed, and centrifuged lysates were incubated in the presence of native calf thymus DNA cellulose as described previously (Pognonec et al. 1989). Flowthrough, wash, and elution fractions were collected, and equivalent amounts of each were immunoprecipitated with an Ets2-specific peptide antiserum and analyzed by SDSPAGE. As shown in Figure 6C, among the four products encoded by the c-ets-2 cDNA, only the nonphosphorylated forms of $58(\mathrm{p} 58)$ and $62 \mathrm{kD}(\mathrm{p} 62)$ display affinity for DNA cellulose. This binding is specific to DNA, because no binding to plain cellulose is observed (data not shown). In contrast, the phosphorylated 60- (p60) and 64-kD (p64) forms are found exclusively in the flowthrough fraction. From these experiments, we conclude that Ets2, like Ets1, binds to DNA cellulose only in its nonphosphorylated state.

\section{Discussion}

In this paper we demonstrate that Ets2 is localized in the nuclei of chicken macrophages, where c-ets-2 products are naturally and abundantly expressed and, like Ets1, only the nonphosphorylated Ets2 products of 58 and 62 $\mathrm{kD}$ are capable of binding to DNA in vitro. Ets 1 and Ets 2 products share two domains of identity of 96 and 175 amino acids near the amino terminus and at the carboxyl terminus, respectively (Boulukos et al. 1988). Therefore, it is likely that one or both of the conserved domains shared between Ets 1 and Ets 2 are required for DNA binding. Recent analyses of deletion mutants in these two conserved domains indicate that the DNAbinding domain appears to be the same for Ets1 and Ets2 and resides in the carboxyl terminus of these products (Boulukos et al. 1990).

We reported previously that Ets 2 is expressed in normal and transformed chicken macrophages (Ghysdael et al. 1986b). In this paper we showed that expression of Ets 2 in these cells is dependent on cMGF stimulation. The cMGF-induced expression of c-ets-2 can be blunted by either down-regulation or inactivation of PKC, suggesting that PKC is involved in the intracellular cMGF signal transduction pathway in macrophages. Consistent with this, we found that Ets 2 expression is also induced after treatment of these cells by TPA and LPS, both of which activate PKC. This induction is at least partially transcriptional because induction of c-ets-2 expression is abolished in the presence of actinomycin D. In macrophages, Ets 1 is weakly expressed and its expression is not induced by CMGF, TPA, or LPS, suggesting a distinct function of these two genes in these cells.

The induction of c-ets-2 is transient in macrophages. We demonstrated that the half-life of c-ets-2 RNA is short compared to most mammalian messages and can be lengthened by cycloheximide treatment. Sequence analysis of a chicken cDNA clone specific to Ets 2 revealed at least three ATTTA motifs located in the $3^{\prime}$ - noncoding AT-rich region (K.E. Boulukos, unpubl.). AUUUA motifs are believed to destabilize mRNA and are characteristic of a number of transiently expressed genes, including c-fos and c-myc (for review, see Shaw and Kamen 1986). Taken together, these results indicate that c-ets-2 is an early gene in its response to cMGF and PKC activators in fully differentiated cells of the myelomonocytic lineage.

Macrophages play an essential role in the inflammatory response and host defense mechanisms against infectious and neoplastic diseases. The cellular functions underlying these activities are acquired in the process of macrophage activation following exposure to external signals, including cytokines and bacterial cell wall products. One of the earliest events associated with macrophage activation is the rapid and transient induction or enhancement of a set of genes that are believed to contribute to the acquisition of functional competence (Hamilton et al. 1986; Introna et al. 1986, 1987; Tannenbaum et al. 1988). In this respect, c-ets-2 resembles these genes in the rapid induction of its expression after LPS or TPA treatment of monocytes or macrophages. Unlike c-fos (Bravo et al. 1987), however, c-ets-2 is not increased after treatment of BMM with the calcium ionophore A23187 or forskolin, an activator of adenylate cyclase (K.E. Boulukos et al., unpubl.). Because Ets 2 products are nuclear and bind to DNA in vitro, the rapid and transient changes in their expression in response to LPS or cytokines may mediate in the nucleus some of the events contributing to the development of functional competence in macrophages.

In contrast to observations in nondividing, fully differentiated macrophages, c-ets-2 gene expression is not induced by cMGF in E26-transformed myeloblasts. These results suggest that the response of macrophages and E26-transformed myeloblasts to cMGF is not the same. Why would cMGF activate c-ets-2 gene expression in macrophages and not in E26-transformed myeloblasts? One possibility is that the expression of the E26transforming protein (p135 gag-myb-ets) in E26-transformed myeloblasts interferes with the signal transduction pathway linking cMGF receptor occupation and c-ets-2 gene expression. Coherent with this hypothesis, TPA treatment of E26-transformed myeloblasts also failed to result in the induction of c-ets-2.

However, cMGF clearly delivers a proliferative signal to E26-transformed myeloblasts because these cells are strictly dependent on cMGF for growth and survival (Leutz et al. 1984). Furthermore, we found that inactivation of p135 gag-myb-ets by a $24-\mathrm{hr}$ shift to $42^{\circ} \mathrm{C}$ of myeloblasts transformed by a temperature-sensitive mutant of E26 in myeloid transformation (Beug et al. 1984) does not result in these cells responding to TPA by c-ets-2 expression (J. Ghysdael, unpubl.). In fact, induction of c-ets-2 expression after TPA treatment occurs only after 3 days of temperature shift when cells have acquired a more mature macrophage-like differentiation phenotype. It is therefore possible that signals elicited by cMGF to induce cell proliferation of immature cells of the myeloid lineage either are different or only partially 
overlap with those mediating differentiated functions in mature cells. This differential signaling could result from the triggering of different cMGF receptors in immature and mature cells of the myeloid lineage or, alternatively, through the same receptor coupled to distinct signal transduction pathways. In any case, our results suggest that regulation of the expression of c-ets-2, at least in myelomonocytic lineage, depends on the maturation state of the cells and is not necessarily or solely linked to cell proliferation.

\section{Materials and methods}

\section{Macrophage preparations and cells}

Chicken BMM were obtained by culturing bone marrow cells for 4-6 days in Dulbecco's modified Eagle medium (DMEM), supplemented with $10 \%$ fetal calf serum and $2 \%$ chicken serum (standard medium) in the presence of $4 \mathrm{U} / \mathrm{ml}$ of cMGF (Leutz et al. 1984). Peritoneal macrophages from BALB/c mice were obtained as described essentially by Hamilton et al. (1986). Three days following intraperitoneal injection with $3 \%$ Brewer's thioglycollate broth, mice were sacrificed and macrophages were obtained after peritoneal washes with RPMI 1640 and calciparine. Peritoneal macrophages were cultured in RPMI 1640 medium supplemented with $10 \%$ fetal calf serum for 24 $\mathrm{hr}$ before LPS induction analyses. The purification of human blood-derived monocytes was described previously (Sariban et al. 1987). Briefly, peripheral blood monocytes were isolated by Ficoll-Hypaque gradient sedimentation and adherence to plastic culture flasks. These adherent cells (activated monocytes) were incubated in RPMI 1640 medium containing $10 \%$ fetal bovine-defined serum for 24-48 hr before experiments were performed. The MC29-transformed HD11 and HBC-1 macrophage cell lines and myeloblast clone transformed by E26ts21 and freshly transformed AMV monoblasts used in this study were generously provided by $\mathrm{H}$. Beug and T. Graf. E26transformed myeloblasts and AMV-transformed monoblasts were maintained in standard medium in the presence of $1 \mathrm{U} / \mathrm{ml}$ cMGF (Leutz et al. 1984).

\section{RNA preparation, cell labeling, and immunoprecipitation analyses}

Total RNA was prepared from cells using guanidinium isothiocyanate. Ten micrograms of RNA was run on formaldehyde gels and transferred overnight to nylon membranes (Amersham). Probe preparation and washing of blots were performed as described previously (Boulukos et al. 1988).

Cells were labeled with L-[35 S $]$ methionine, lysed in RIPA buffer [RIPA: $150 \mathrm{~mm} \mathrm{NaCl}, 10 \mathrm{~mm}$ Tris- $\mathrm{HCl}$ (pH 7.4), $1 \mathrm{~mm}$ EDTA, $0.5 \%$ sodium deoxycholate, $0.1 \%$ SDS, $1 \%$ Triton $\mathrm{X}-100$, and $1 \%$ aprotinin (Sigma)l and immunoprecipitated as described previously (Ghysdael et al. 1986b). The standard ets antiserum used in this study was generated in rabbits, using a bacterially expressed protein corresponding to the carboxy-terminal domain of v-ets (Ghysdael et al. 1986a). The Ets2-specific peptide antiserum corresponding to the last 13 amino acids of the carboxyl terminus of Ets2 was obtained as described in Boulukos et al. (1988).

\section{Immunofluorescence studies}

Immunofluorescence analyses were performed as described previously (Boulukos et al. 1988). Briefly, cells of the macrophage line HDl1 were fixed in $3.5 \%$ paraformaldehyde $48 \mathrm{hr}$ after transfection, treated with $0.15 \mathrm{M}$ ethanolamine, and permeabilized in $0.2 \% \mathrm{NP}-40$. Cells were incubated with a control nonimmune rabbit serum, an Ets2-specific peptide antiserum (Boulukos et al. 1988), or the Ets2-specific peptide antiserum blocked with an excess of its peptide immunogen. After washing, cells were incubated with FITC-conjugated swine anti-rabbit immunoglobulins (Dakopatts). Immunofluorescence was examined using a Zeiss epifluorescence microscope.

\section{DNA-binding experiments}

DNA-binding analyses were performed as described previously (Pognonec et al. 1989). Briefly, COS-1 cells were transfected with PKCR3-Ck-3.1 (Boulukos et al. 1988) and labeled with $\mathrm{L}-\left[{ }^{35} \mathrm{~S}\right]$ methionine. Labeled cells were resuspended in TDT buffer $[10 \mathrm{~mm}$ Tris- $\mathrm{HCl}(\mathrm{pH} 7.4), 1 \mathrm{~mm}$ DTT, $0.1 \%$ Triton $\mathrm{X}-100,1 \mathrm{mM}$ EDTA, $10 \mu \mathrm{g} / \mathrm{ml}$ leupeptin, $100 \mu \mathrm{g} / \mathrm{ml}$ paramethylsulfonyl fluoride, and $1 \%$ aprotinin (Sigma)], homogenized, and nuclei pelleted at $1000 \mathrm{~g}$ for $5 \mathrm{~min}$. The supernatant was clarified by centrifugation at $100,000 \mathrm{~g}$ and $4^{\circ} \mathrm{C}$ for $20 \mathrm{~min}$. Nuclei were incubated for $10 \mathrm{~min}$ in $0.5 \mathrm{M} \mathrm{NaCl}-\mathrm{TDT}$ buffer and centrifuged at $12,000 \mathrm{~g}$, and the nuclear extract was pooled with the first supernatant. After adjusting the final salt concentration to $50 \mathrm{~mm} \mathrm{NaCl}$, an aliquot of this preparation was loaded on double-stranded DNA or plain cellulose columns equilibrated in TDT buffer containing $50 \mathrm{mM} \mathrm{NaCl}$. After incubation for $45 \mathrm{~min}$, the flowthrough fraction was collected, the column was washed extensively in $50 \mathrm{mM} \mathrm{NaCl}-\mathrm{TDT}$, and finally eluted in TDT buffer containing $1 \mathrm{M} \mathrm{NaCl}$. Equivalent amounts of each fraction were adjusted to RIPA buffer conditions, immunoprecipitated, and analyzed by SDS-PAGE.

\section{Acknowledgments}

We thank H. Beug, A. Leutz, and T. Graf for their generous gifts of E26- and AMV-transformed myeloblast and monoblast clones and purified cMGF. We also thank M.C. Bouchez and N. Devassine for secretarial assistance. This work was supported by funds from the Institut National de la Santé et de la Recherche Médicale (INSERM), Centre National de la Recherche Scientifique (CNRS), Institut Pasteur de Lille, and Association pour la Recherche sur le Cancer (ARC).

\section{References}

Adams, D.O. and T.A. Hamilton. 1984. The cell biology of macrophage activation. Annu. Rev. Immunol. 2: 283-318.

Bonvini, E., T. Hoffman, R.B. Herberman, and L. Varesio. 1986. Selective augmentation by recombinant interferon of the intracellular content of S-adenosylmethionine in murine macrophages. I. Immunol. 39: 2596-2604.

Berridge, M.J. and R.F. Irvine. 1984. Inositol triphosphate, a novel second messenger in cellular signal transduction. $\mathrm{Na}$ ture 312: 315-321.

Beug, H., A. Leutz, P. Kahn, and T. Graf. 1984. Ts mutants of E26 leukemia virus allow transformed myeloblasts, but not erythroblasts or fibroblasts, to differentiate at nonpermissive temperature. Cell 39: 579-588.

Bhat, N.K., R.J. Fisher, S. Fujiwara, R. Ascione, and T.S. Papas. 1987. Temporal and tissue-specific expression of mouse ets genes. Proc. Natl. Acad. Sci. 84: 3161-3165.

Boulukos, K.E., P. Pognonec, A. Begue, F. Galibert, J.C. Gesquière, D. Stéhelin, and J. Ghysdael. 1988. Identification in 
chickens of an evolutionarily conserved cellular ets-2 gene (c-ets-2) encoding nuclear proteins related to the products of the c-ets proto-oncogene. EMBO I. 7: 697-705.

Boulukos, K.E., P. Pognonec, B. Rabault, A. Bengue, and J. Ghysdael. 1989. Definition of an Etsl protein domain required for nuclear localization and binding in vitro. Mol. Cell. Biol. 9: 5718-5721.

Bravo, R., M. Neuberg, J. Burckhardt, J. Almendral, R. Wallich, and R. Muller. 1987. Involvement of common and cell typespecific pathways in c-fos gene control: Stable induction by cAMP in macrophages. Cell 48: 251-260.

Chen, J.H. 1985. The proto-oncogene c-ets is preferentially expressed in lymphoid cells. Mol. Cell. Biol. 5: 2993-3000.

- 1988. Complementary DNA clones of chicken protooncogene $c$-ets: Sequence divergence from the viral oncogene $v$-ets. Oncogene Res. 2: 371-384.

Duterque-Coquillaud, M., D. Leprince, A. Flourens, C. Henry, J. Ghysdael, B. Debuire, and D. Stéhelin. 1988. Cloning and expression of chicken p54cets $\mathrm{cDNAs:}$ The first p54c-ets coding exon is located in the $40 \mathrm{kbp}$ genomic domain unrelated to v-ets. Oncogene Res. 2: 335-344.

Gegonne, A., D. Leprince, M. Duterque-Coquillaud, B. Vandenbunder, A. Flourens, J. Ghysdael, B. Debuire, and D. Stéhelin. 1987. Multiple domains for the chicken cellular sequences homologous to the $v$-ets oncogene of the E26 retrovirus. Mol. Cell. Biol. 7: 806-812.

Ghysdael, J., A. Gegonne, P. Pognonec, D. Dernis, D. Leprince, and D. Stéhelin. 1986a. Identification and preferential expression in thymic and bursal lymphocytes of a c-ets oncogene encoded Mr 54,000 cytoplasmic protein. Proc. Natl. Acad. Sci. 83: 1714-1718.

Ghysdael, J., A. Gegonne, P. Pognonec, K. Boulukos, D. Leprince, D. Dernis, C. Lagrou, and D. Stéhelin. 1986b. Identification in chicken macrophages of a set of proteins related to, but distinct from, the chicken cellular c-ets-encoded protein p54-ets. EMBO I. 5: 2251-2256.

Golay, J., M. Introna, and T. Graf. 1988. A single point mutation in the $v$-ets oncogene affects both erythroid and myelomonocytic cell differentiation. Cell 55: 1147-1158.

Graf, T., N. Oker-Blom, T.G. Todorov, and H. Beug. 1979. Transforming capacities and defectiveness of avian leukemia viruses OK10 and E26. Virology 99: 431-436.

Hamilton, T.A. and D.O. Adams. 1987. Molecular mechanisms of signal transduction in macrophages. Immunol. Today 8: $151-158$.

Hamilton, T.A., M.M. Jansen, S.D. Somers, and D.O. Adams. 1986. Effects of bacterial lipopolysaccharide on protein synthesis in murine peritoneal macrophages: Relationship to activation for macrophage tumoricidal function. $J$. Cell. Physiol. 128: 9.

Introna, M., R.C. Bast, Jr., P.A. Johnston, D.O. Adams, and T.A. Hamilton. 1987. Homologous and heterologous desensitization of proto-oncogene c-fos expression in murine peritoneal macrophages. I. Cell. Physiol. 131: 36.

Introna, M., T.A. Hamilton, R.E. Kaufman, D.O. Adams, and R.C. Bast. 1986. Treatment of murine peritoneal macrophages with bacterial lipopolysaccharide alters expression of c-fos and c-myc oncogenes. I. Immunol. 137: 2711-2715.

Kawamoto, S. and H. Hidaka. 1984. 1-(5-Isoquinolinesulfonyl)2-methylpiperazine (H-7) is a selective inhibitor of protein kinase $\mathrm{C}$ in rabbit platelets. Biochem. Biophys. Res. Commun. 125: 258-264.

Kiyotaki, C. and B.R. Bloom. 1984. Activation of murine macrophage cell lines. Possible involvement of protein kinases in stimulation of superoxide production. I. Immunol. 133: 923-931.
Leprince, D., A. Gegonne, J. Coll, C. DeTaisne, A. Schneeberger, C. Lagrou, and D. Stéhelin 1983. A putative second cell-derived oncogene of the avian leukemia retrovirus E26. Nature 306: 395-397.

Leprince, D., M. Duterque-Coquillaud, R.P. Li, C. Henry, A. Flourens, B. Debuire, and D. Stéhelin. 1988. Alternative splicing within the chicken c-ets-1 locus: Implications for transduction within the E26 retrovirus of the c-ets proto-oncogene. J. Virol. 62: 3233-3241.

Leutz, A., H. Beug, and T. Graf. 1984. Purification and characterization of $\mathrm{CMGF}$, a novel chicken myelomonocytic growth factor. $E M B O$ I. 3: 3191-3197.

Leutz, A., K. Damm, E. Sterneck, E. Kowenz, S. Ness, R. Frank, H. Gausepohl, Y.C.E. Pan, J. Smart, M. Hayman, and T. Graf. 1989. Molecular cloning of the chicken myelomonocytic growth factor (cMGF) reveals relationship to interleukin 6 and granulocyte stimulating factor. EMBO $\mathrm{f}$. 8: $175-181$.

Moscovici, C., J. Samarut, L. Gazzolo, C.V. Murra, and M.G. Moscovici. 1981. Myeloid and erythroid neoplastic responses to avian defective leukemia viruses in chickens and in quail. Virology 113: 765-768.

Moscovici, M.G., P. Jurdic, J. Samarut, L. Gazzolo, C.V. Murra, and C. Moscovici. 1983. Characteristics of the hemopoietic target cells for the avian leukemia virus, E26. Virology 129: $65-78$.

Nunn, M.F. and T. Hunter. 1989. The ets sequence is required for induction of erythroblastosis in chickens by avian retrovirus E26. J. Virol. 63: 398-402.

Nunn, M.F., P.M. Seeburg, C. Moscovici, and P.H. Duesberg. 1983. Tripartite structure of the avian erythroblastosis vinus E26 transforming gene. Nature 306: 391-395

Pognonec, P., K.E. Boulukos, J.C. Gesquìre, D. Stéhelin, and J. Ghysdael. 1988. Mitogenic stimulation of thymocytes results in the calcium-dependent phosphorylation of c-ets-1 proteins. EMBO I. 7: 977-983.

Pognonec, P., K.E. Boulukos, and J. Ghysdael. 1989. The c-ets-1 protein is chromatin associated and binds to DNA in vitro. Oncogene 4: 691-697.

Radke, K., H. Beug, S. Kornfeld and T. Graf. 1982. Transformation of both erythroid and myeloid cells by E26, an avian leukemia virus that contains the myb gene. Cell 31: 643653.

Radzioch, D., B. Bottazzi, and L. Varesio. 1987. Augmentation of c-fos mRNA expression by activators of protein kinase $\mathrm{C}$ in fresh, terminally differentiated resting macrophages. Mol. Cell. Biol. 7: 595-599.

Rao, V.N., T.S. Papas, and E.S.P. Reddy. 1987. erg, a human etsrelated gene on chromosome 21: Alternative splicing, polyadenylation, and translation. Science 237: 635-639.

Rao, V.N., K. Huebner, M. Isobe, A. Ar-Rushdi, C.M. Croce, and E.S.P. Reddy. 1989. elk, Tissue-specific ets-related genes on chromosomes $\mathrm{X}$ and 14 near translocation breakpoints. Science 244: 66-70.

Reddy, E.S.P., V.N. Rao, and T.S. Papas. 1987. The erg gene: A human gene related to the ets oncogene. Proc. Natl. Acad. Sci. 84: 6131-6135.

Roussel, M., S. Saule, C. Lagrou, C. Rommens, H. Beug, T. Graf, and D. Stéhelin. 1979. Three new types of viral oncogene of cellular origin specific for hemaetopoietic cell transformation. Nature 281: 453-455.

Sariban, E., R. Luebbers, and D. Kuke. 1987. Transcriptional and posttranslational control of c-fos gene expression in human monocytes. Mol. Cell. Biol. 8: 340-346.

Shaw, G., and R. Kamen. 1986. A conserved AU sequence form the 3 'untranslated region of GM-CSF mRNA mediates se- 
lective mRNA degradation. Cell 46: 659-667.

Tannenbaum, C.S., T.J. Koerner, M.M. Jansen, and T.A. Hamilton. 1988. Characterization of lipopolysaccharide-induced macrophage gene expression. I. Immunol. 140: 3640-3645.

Todd, R.F. III, P.A. Alvarez, D.A. Brott, and D.Y. Liu. 1985. Bacterial lipopolysaccharide, phorbol myristate acetate, and muramyl dipeptide stimulate the expression of a human monocyte surface antigen, Mo3e. I. Immunol. 135: 38693877.

Vassali, J.D., J.M. Dayer, and A. Wohlwend. 1984. Concomitant secretion of prourokinase and a plasminogen activator specific inhibitor by cultured human monocytes-macrophages. J. Exp. Med. 159: 1653-1668.

Watson, D.K., M.J. McWilliams-Smith, M.F. Nunn, P.H. Duesberg, S.J. O'Brien, and T.S. Papas. 1985. The ets sequence from the transforming gene of avian erythroblastosis. Proc. Natl. Acad. Sci. 82: 7294-7298. 


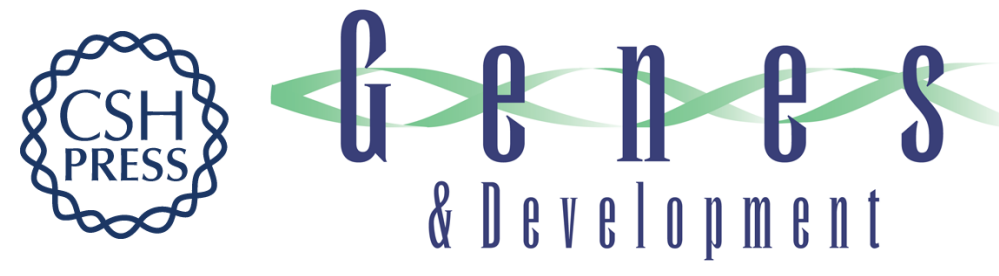

\section{Rapid and transient expression of Ets2 in mature macrophages following stimulation with CMGF, LPS, and PKC activators.}

K E Boulukos, P Pognonec, E Sariban, et al.

Genes Dev. 1990, 4:

Access the most recent version at doi:10.1101/gad.4.3.401

References This article cites 44 articles, 17 of which can be accessed free at: http://genesdev.cshlp.org/content/4/3/401.full.html\#ref-list-1

License

Email Alerting

Service

Receive free email alerts when new articles cite this article - sign up in the box at the top right corner of the article or click here.

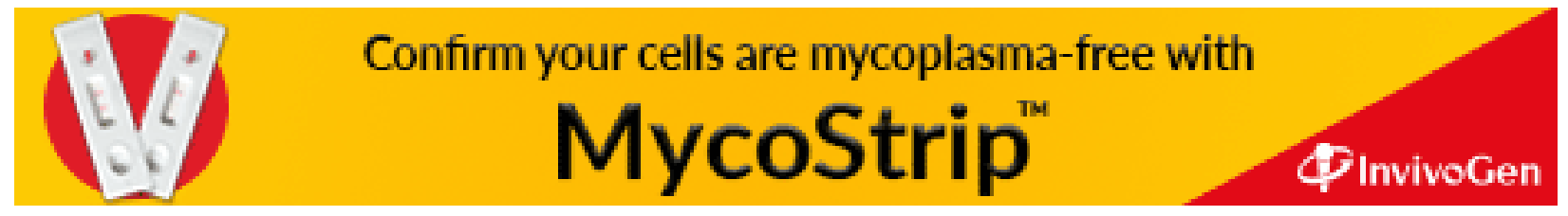

